\title{
bofC encodes a putative forespore regulator of the Bacillus subtilis $\sigma^{\mathrm{K}}$ checkpoint
}

\author{
Manuel Gomez† and Simon M. Cutting $\ddagger$
}

Author for correspondence: Simon M. Cutting. Tel: +44 1784 443760. Fax: +44 1784434326. e-mail: s.cutting@rhbnc.ac.uk

Department of

Microbiology, University of Pennsylvania School of Medicine, Philadelphia, PA 19104-6076, USA

\begin{abstract}
A mutation, bofC1, that restores $\sigma^{\mathrm{K}}$ activation in Bacillus subtilis strains unable to produce active $\sigma^{\sigma}$ has been identified. This mutation defines a new sporulation gene, bof $C$, that has been cloned and sequenced and encodes a $19 \mathrm{kDa}$ protein. bofC is transcribed in the forespore by RNA polymerase associated with the transcription factors $\sigma^{F}\left(E \sigma^{F}\right)$ and $\sigma^{\sigma}\left(E \sigma^{G}\right)$. BofC acts negatively on SpoIVB and the results described suggest that BofC regulates SpolVB activity and its intercompartmental signalling role in the $\sigma^{\mathrm{K}}$ checkpoint.
\end{abstract}

Keywords: Bacillus subtilis, sporulation, checkpoint, gene regulation

\section{INTRODUCTION}

Spore formation is the predominant response of Bacillus subtilis to conditions of nutrient depletion. Development of the spore is dependent on coordinated programmes of gene expression in the two compartments (mother cell and forespore) of the differentiating cell. Controlling this are five sigma factors $\left(\sigma^{\mathrm{H}}, \sigma^{\mathrm{F}}, \sigma^{\mathrm{E}}, \sigma^{\mathrm{G}}\right.$ and $\left.\sigma^{\mathrm{K}}\right)$ that confer different promoter specificities upon the RNA polymerase holoenzyme (Errington, 1993).

In the mother cell $\sigma^{\mathrm{K}}$ directs the expression of a large number of genes whose products are required for the final stages of spore maturation (e.g. synthesis of the proteinaceous coat which encases the dormant spore (Sandman et al., 1988; Zheng \& Losick, 1990). $\sigma^{\mathrm{K}}$ is synthesized initially as an inactive precursor, termed pro- $\sigma^{\mathrm{K}}$, which must be cleaved at its $\mathrm{N}$-terminus to be rendered functional (Lu et al., 1990). Processing of pro$\sigma^{\mathrm{K}}$ is controlled by an intercompartmental signal transduction pathway, termed the ' $\sigma^{\mathbf{K}}$ checkpoint', that couples mother cell $\sigma^{\mathrm{K}}$-directed gene expression to $\sigma^{\mathrm{G}}$ dependent gene expression in the forespore (Cutting $e t$ al., 1990).

The major components of the $\sigma^{\mathrm{K}}$ checkpoint have been identified. In the mother cell, SpoIVFA, BofA and SpoIVFB are thought to form a hetero-oligomeric complex that resides in the outermost membrane layer of the forespore and controls processing of pro- $\sigma^{\mathrm{K}}$

† Present address: Public Health Research Institute, 455 1st Avenue, New York, NY 10016, USA.

¥Present address: School of Biological Sciences, Royal Holloway University of London, Egham, Surrey TW20 OEX, UK.

The EMBL accession number for the sequence reported in this paper is X93081.
(Cutting et al., 1991b; Ricca et al., 1992; Resnekov et al., 1996). SpoIVFB is the most likely candidate for the proteolytic enzyme although proteolytic activity has not been demonstrated ( $\mathrm{Lu}$ et al., 1995) and BofA and SpoIVFA are inhibitors of SpoIVFB activity. Pro- $\sigma^{\mathrm{K}}$ proteolysis is dependent on a signal originating from the forespore that relieves SpoIVFA and BofA-mediated inhibition of SpoIVFB. Accordingly, mutations that inactivate the BofA or SpoIVFA polypeptides (termed bof mutations, bypass of forespore gene expression) allow constitutive activity of SpoIVFB in the absence of forespore signalling (Cutting et al., 1990). The signal itself is the product of $\sigma^{\mathrm{G}}$-dependent gene expression within the forespore and one gene product, the $46 \mathrm{kDa}$ SpoIVB protein, has been identified as the essential signalling molecule (Cutting et al., 1991a). Genetic analysis has also shown that SpoIVB is most likely the only $\sigma^{\mathrm{G}}$-dependent gene product necessary for signal transmission (Gomez et al., 1995). SpoIVB contains a putative signal sequence that might allow it to transit the inner forespore membrane and directly, or through an intermediate enzymic reaction it catalyses, stimulate processing of pro- $\sigma^{\mathrm{K}}$.

The $\sigma^{\mathrm{K}}$ checkpoint provides an elegant mechanism for fine-tuning gene expression and introduces a timing mechanism ensuring that activation of $\sigma^{\mathrm{K}}$ proceeds only when the appropriate stage of forespore development has been attained. In the absence of the checkpoint (e.g. in bof $A$ or spoIVFA defective mutants), $\sigma^{\mathrm{k}}$-directed gene expression proceeds prematurely, resulting in the early expression of the $\sigma^{\mathrm{K}}$ regulon which, in turn, results in a reduction in sporulation efficiency and the production of aberrantly formed spores (Cutting et al., 1990).

We report here the identification of a new foresporeexpressed gene, bofC, which encodes a putative regu- 
lator of SpoIVB function. The bofC gene product may therefore be involved in the fine-tuning of the $\sigma^{\mathrm{K}}$ checkpoint.

\section{METHODS}

Bacterial strains. Strains of $B$. subtilis are listed in Table 1. All strains used in this work were congenic derivatives of the prototrophic, $\mathrm{Spo}^{+}$, strain PY79. Strains lysogenic for $S P \beta:$ : gerE-lac $Z$ are referred to in the text by the name or allele of the strain lysogenized.

General methods. Standard B. subtilis methodology, including genetic analysis, was as described by Harwood \& Cutting (1990). Sporulation was induced using the 'resuspension method' (Nicholson \& Setlow, 1990). SP $\beta$ specialized transduction were performed using a lysate prepared from strain SC433 (SP $\beta$ : : gerE-lacZ) as described by Cutting \& VanderHorn (1990). Primer extension reactions and preparation of $B$. subtilis mRNA were described previously (Cutting et al., 1991b).

Isolation and mapping of the bofC1 mutation. The bofC1 mutation was identified inadvertently in a mutagenic screen for dominant alleles in the spoIVF operon. Cells of strain


mutagenized as described previously (Cutting et al., 1991b) and DNA from these cells was used to transform strain SC1309 (spolIIGA1 spoIVF ${ }^{+}$amyE: :spoIVF ${ }^{+}$) followed by selection for MLS $^{\mathrm{R}}$ (conferred by the transposon insertion chr: : Tn917sHU144, which is approximately $30 \%$ linked, by transformation, to $s p o I V F)$. MLS ${ }^{R}$ transformants were screened for their Pig phenotype on DSM sporulation agar plates and one $\mathrm{Pig}^{+} \mathrm{Spo}^{-}$colony from about 100000 examined was identified. The $\mathrm{Pig}^{+}$phenotype (the brown coloration of sporulating colonies) is a marker of $\sigma^{\mathrm{K}}$-directed gene expression and would, in this situation, result from a mutation bypassing the requirement of $\sigma^{\mathrm{G}}$ (encoded by spollIG) for activation of $\sigma^{\mathrm{K}}$ in the mother cell compartment. The pig ${ }^{+}$ mutation identified was $30 \%$ linked, by transformation, to the

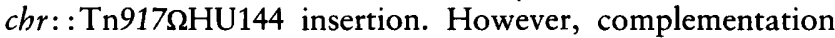
analysis by transformation with integrative plasmids (pSC212, pSC217, pSC220 and pSC223) that contain segments of the spoIVF operon (Cutting et al., 1991b) indicated that the mutation was not allelic to spoIVF. To map the $p^{+}{ }^{+}$mutation, which was henceforth designated bofC1, we performed twoand three-factor transformation crosses using markers in the $s p o I V F-s p o V B$ region and complementation analysis with integrative plasmids carrying segments of the nic-spoVB region of the chromosome (see Fig. 1 and Popham \& Stragier, 1991).

Plasmid constructions. pDG850, pDG851, pDG855, pDG863 and pDG873 were provided by P. Stragier (Fig. 1 and Popham \& Stragier, 1991). pDG855 $\Delta$ SacI and pDG855 $E$ EcoRV were constructed by cleaving pDG855 with NseI and either SacI or EcoRV, blunting ends with T4 DNA polymerase and ligation. pSC60, pSC61, pSC63, pMG5, pMG7 and pMG28 were obtained by subcloning fragments from pDG855 (see Fig. 1) into the integrative vector pSGMU2 (Perego, 1993). pMG4 was constructed by 'chromosome walking' with PstI, using chromosomal DNA from strain PY79 transformed with pMG5. pMG17 was constructed by cloning a 954 bp PCRamplified fragment of DNA containing the promoter and coding regions of bofC (nt 1493-2446 of Fig. 3) into the BamHI-HindIII sites of pDG364. pDG364 allows insertion of cloned DNA at the amyE locus of the chromosome (Cutting \& Vander-Horn, 1990).
Sequencing of the bofC chromosomal region. To sequence the bofC chromosomal region denatured double-stranded DNA templates of the plasmids pSC60, pSC61, pSC63, pMG4, pMG5 and pMG7 were used as sequencing templates. The cloned inserts in these plasmids are flanked by sites recognized by the M13 'Universal' Forward $(-40)$ and Reverse sequencing primers. The sequence obtained using these primers was extended by synthesizing additional sequencing primers using the new sequence information generated. All restriction sites were crossed, the DNA sequenced on both strands and several independent sequence determinations made.

Sequencing the bofC1 allele. To sequence bofC1 two primers, F9FOR and F9REV, were used to amplify chromosomal DNA of strain SC1643. F9FOR (GGGAATTCACGGCGTATCTTTTGCTGGG; nt 1713-1732 of Fig. 3) and F9REV (GGAAGCTTGGATTCGGCGTGAAAATCTGATAG; nt 2446-2423 of Fig. 3) annealed upstream and downstream of the region known to contain bofC1 (determined from genetic mapping experiments). The $734 \mathrm{bp} \mathrm{PCR-amplified} \mathrm{product}$ was digested to completion with HindIII and EcoRI and cloned into the integrative plasmid pSGMU2 to create pSC67. Competent cells of SC500 (spoIIIG $\Delta 1$ ) were transformed with pSC67 DNA and approximately $60 \%$ of $\mathrm{Cm}^{\mathrm{R}}$ transformants were $\mathrm{Pig}^{+}$due to introduction of the bofC1 mutation. The entire cloned fragment in pSC67 was sequenced on both DNA strands using primers that annealed to the polylinker cloning sites in PSGMU2 and with other oligonucleotide primers that annealed to the cloned DNA. Several independent plasmid clones obtained using this procedure were sequenced to authenticate our sequence determination.

Construction of the bofC: : neo insertional mutant. To create an insertional mutation in bofC a neomycin-resistance cassette (neo) was inserted into the unique BspEI site within the bofC ORF. The neo cartridge was isolated as a $1.3 \mathrm{~kb}$ Smal fragment from plasmid pBEST501 (Itaya et al., 1989) and ligated to pSC60 (see above) which had been linearized (BspEI) and blunt-ended with S1 nuclease. Following transformation into Escherichia coli and selection for $\mathrm{Nm}^{\mathrm{R}}\left(25 \mu \mathrm{g} \mathrm{ml}^{-1}\right)$ a plasmid, pMG3, was isolated which contained the neomycin-resistance cassette inserted at the BspEI site (see Fig. 1). pMG3 was linearized (HindIII) and used to transform B. subtilis strain PY79 with selection for $\mathrm{Nm}^{\mathrm{R}}\left(2.5 \mu \mathrm{g} \mathrm{ml}^{-1}\right)$. Using this procedure $\mathrm{Nm}^{\mathrm{R}}$ transformants should only arise by a double crossover (marker replacement) where the bofC::neo construct would replace homologous DNA at the bofC locus. To confirm that $\mathrm{Nm}^{\mathrm{R}}$ transformants had arisen by marker replacement, and not due to integration of circular plasmid DNA by a Campbell-type mechanism, colonies were checked for sensitivity to chloramphenicol (pMG3 carries the cat gene). One such $\mathrm{Nm}^{R} \mathrm{Cm}^{\mathrm{s}}$ transformant was isolated (strain MG54) which contained a stable bofC: :neo insertional mutation.

Construction of strains containing bofC at the amyE locus. To generate strains partially diploid for bofC we introduced the bofC gene at the amyE locus using pMG17, whose construction has been described above. In pMG17 the bofC and cat genes are flanked by the front and back portions of the amyE gene (Cutting \& Vander-Horn, 1990). pMG17 was linearized $(X h o I)$ and used to transform appropriate strains with selection for $\mathrm{Cm}^{\mathrm{R}}$. Transformants arising from a marker replacement (double crossover) recombination between the $a m y E(\mathrm{~F})-b o f C-c a t-a m y E(\mathrm{~B})$ construct in pMG17 and the chromosomal copy of amyE were identified by their Amy phenotype (Cutting \& Vander-Horn, 1990). 
Table 1. Bacillus subtilis strains

\begin{tabular}{|c|c|c|}
\hline Strain & Genotype & Source/reference \\
\hline PY79 & $s p o^{+}$ & Youngman et al. (1984) \\
\hline SC433 & $S P \beta:$ :gerE-lacZ & Cutting et al. (1989) \\
\hline BSA $80^{*}$ & sigB314 rbsU: :kan & $\begin{array}{l}\text { B. Haldenwang (University of } \\
\text { Texas Health Science Center, } \\
\text { San Antonio) }\end{array}$ \\
\hline $1 \mathrm{~A} 616^{*}$ & nic-82: : Tn917 trpC2 SPBc2 & BGSC $†$ \\
\hline BK556 & spoIVCB23 & Kunkel et al. (1989) \\
\hline VO1088* & spoIVBA: : spc trpC2 & Oke (1994) \\
\hline SC500 & spoIIIGA1 & Cutting et al. (1990) \\
\hline SC692 & spollIG 1 metB5 & Lab. stock \\
\hline SC745 & bofB8 spollIG 11 & Cutting et al. (1990) \\
\hline SC776 & bofB8 cat & Cutting et al. (1990) \\
\hline SC1008 & 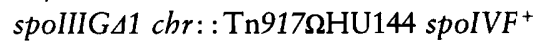 & Lab. stock \\
\hline SC1158 & spoIID66 & Cutting et al. (1991a) \\
\hline SC1159 & spollAC1 & Cutting et al. (1991a) \\
\hline SC1163 & spolIG55 & Cutting et al. (1991a) \\
\hline SC1297 & spolVF ${ }^{+}$amyE: :spolVF ${ }^{+}$ & Cutting et al. (1991b) \\
\hline SC1309 & spollIG $\Delta 1$ amyE : :spoIVF ${ }^{+}$spoIVF $^{+}$ & From SC1297 into SC500 \\
\hline SC1367 & spoIIIG $\triangle 1$ amyE: : spoIVF bofC1 & This work \\
\hline SC1643 & bofC1 spollIG 1 & This work \\
\hline SC1703 &  & This work $\ddagger$ \\
\hline SC1704 & spolllA53 chr: :Tn917sHU144 & This work $\ddagger$ \\
\hline MG24 & $a m y E:$ : bofC-lacZ & This work \\
\hline MG51 & $c s b X:: n e o$ & Gomez \& Cutting (1997) \\
\hline MG54 & bofC: : neo & This work \\
\hline MG57 & csbX: : neo spollIG 11 & From MG51 into SC500 \\
\hline MG60 & bofC: : neo spollIG $\Delta 1$ & From MG54 into SC500 \\
\hline MG101 & spoIVBA: : spc & From VO1088 into PY79 \\
\hline MG103 & amyE: : bofC-lacZ spoIIIG $\Delta 1$ & From $\mathrm{MG} 24$ into SC500 \\
\hline MG117 & bofC: : neo spolVBA : :spc & From MG54 into MG101 \\
\hline MG126 & bofB8 cat spolVBA: :spc & From MG101 into SC776 \\
\hline MG196 & bofC: : bofC-lacZ & This work \\
\hline MG237 & sigB314 rbsU: :kan & From BSA80 into PY79 \\
\hline MG242 & sigB314 amyE: :bofC-lacZ rbsU::kan & From MG24 into MG237 \\
\hline MG243 & sigB314 bofC: : bofC-lacZ rbsU: :kan & From MG196 into MG237 \\
\hline MG253 & csbX: : neo bofC1 spollIG 1 & This work $\$$ \\
\hline MG257 & $\operatorname{csbX}:$ : neo bofC1 & This work $\$$ \\
\hline MG291 & spoIVBA: : spc csbX: : neo bofC1 & From MG257 into MG101\| \\
\hline
\end{tabular}

* These strains are not isogenic with PY79.

† Bacillus Genetic Stock Center.

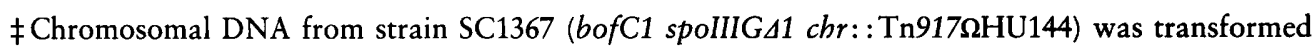
into spolllA53 cells (strain SC615; Cutting et al., 1991a) using non-saturating DNA concentrations (less than $50 \mathrm{ng} \mathrm{ml}^{-1}$ ). Selection was made for MLS ${ }^{\mathrm{R}}$ conferred by $c h r:: \mathrm{Tn} 917 \Omega \mathrm{HU} 144$, which is $30 \%$ linked to bofC1 by transformation. Two isolates (SC1703 and SC1704) were identified from this cross and their genotypes confirmed by appropriate backcrosses.

\A silent neomycin insertion in the $c s b X$ ORF ( $c s b X::$ neo; Gomez \& Cutting, 1997) was introduced into SC1643 (spoIIIGA1 bofC1) cells to create MG253. Next, chromosomal DNA prepared from MG253 was introduced into wild-type cells (PY79) with selection for $\mathrm{Nm}^{\mathrm{R}}$. One transformant was isolated (MG257) which was spoIIIG ${ }^{+}$and the presence of the bofC1 allele confirmed by backcrossing into a spoIIIG mutant strain.

|| Chromosomal DNA prepared from MG257 was introduced into MG101 with selection for $\mathrm{Nm}^{\mathrm{R}}$. More than $95 \%$ of colonies contained bofC1 by co-recombination which was verified by backcrossing. 
(a)

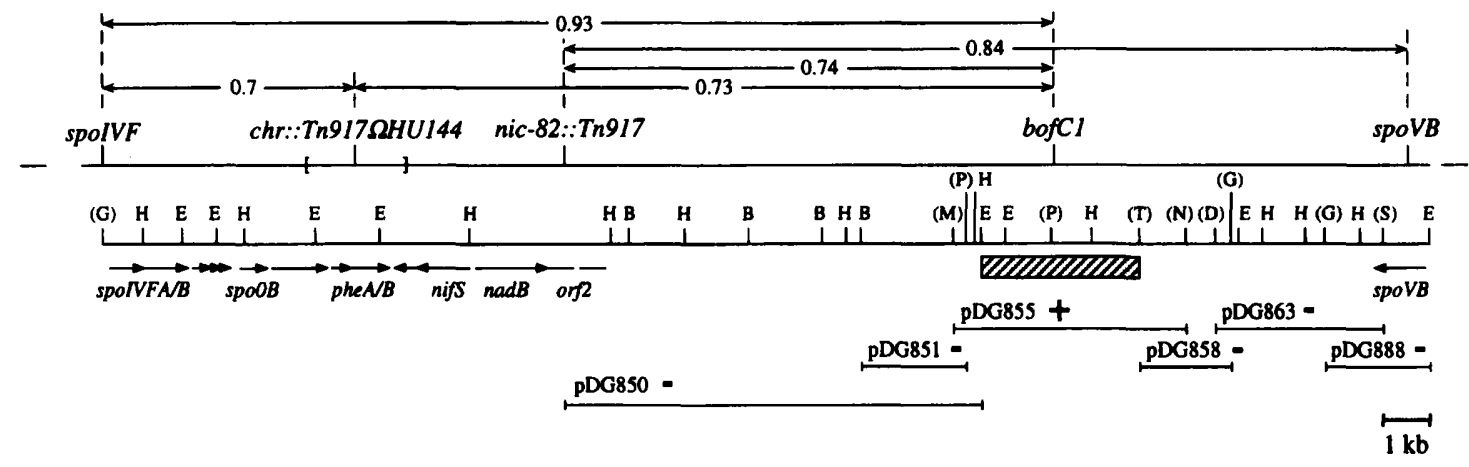

(b)

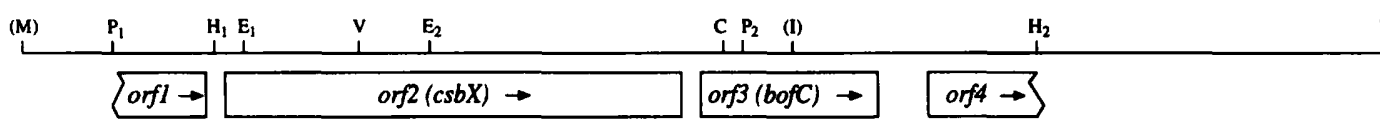

T

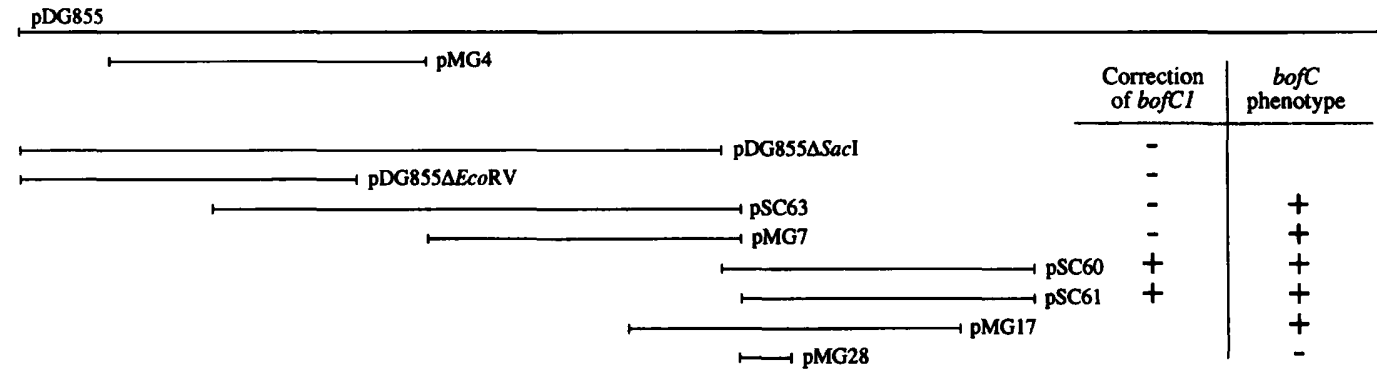

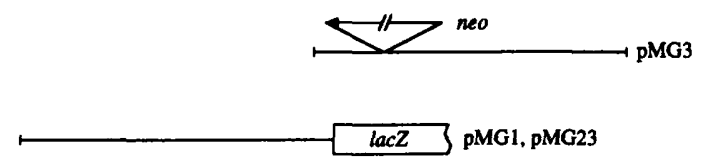

$0.5 \mathrm{~kb}$

Fig. 1. Physical map of the bofC region of the chromosome. (a) Physical map of the bofC chromosomal region. The map shows (to scale) the $27 \mathrm{~kb}$ region of DNA beginning at the spolVF locus and extending to the spoVB gene. This region of the chromosome has been cloned and partially sequenced and the map constructed from other work describing the characterization of the SpoIVF, spoOB, pheA, nifS, nadB and spoVB loci (Cutting et al., 1991b; Popham \& Stragier, 1991; Sun \& Setlow, 1993; Trach \& Hoch, 1989). The physical map linking the nadB locus with DNA contained in pDG851 has been surmised from published work but not confirmed by Southern hybridization analysis. Putative ORFs are indicated by arrows, the direction indicating the transcriptional orientation. Known genetic loci are shown below the arrows. Genetic markers used to map the bofC1 mutation are shown above the physical map together with map linkages [expressed as (100-\% co-transformation)/100]. The precise position of chr::Tn917SHU144 is not known but is less than $1 \mathrm{~kb}$ (to either side) from the pheA gene. The cloned segments of DNA contained in the integrative plasmids, pDG850, pDG851, pDG855, pDG858, pDG863 and pDG888, used to determine the chromosomal position of bofC1 are shown. The $+I-$ symbol indicates whether the corresponding plasmid was able to correct, by integrative recombination, the bofC1 mutation that was located in the $3.3 \mathrm{~kb}$ region (indicated as a striped bar). (b) An expanded physical map of the $5 \mathrm{~kb}$ DNA insert contained in plasmid pDG855. The rectangles below the map show the four ORFs found in the 2664 bp region of DNA sequenced between the Pstl and HindIII sites. The bottom of the figure shows the cloned inserts in the indicated integrational plasmids used to localize the bof 1 mutation and for sequence analysis. The adjacent table indicates whether the cloned insert in these plasmids was able to correct, by integrative recombination, the bofC1 mutation as described in the text. The table also shows whether plasmids pSC60, pSC61, pSC63, pMG7 and pMG28 disrupted the bofC transcriptional unit following integration into the bofC locus. Disruption of bofC caused a BofC phenotype $(-)$ and was used to define the borders of the bofC locus. The cloned insert in pMG17 was generated by PCR amplification, and used for in trans complementation analysis. The construction of the bofC: :neo insertional mutation is schematically illustrated as well as the cloned DNA used to construct the transcriptional fusion of bofC to lacZ. Restriction sites: EcoRI (E), HindIII (H), BamHI (B), Bglll (G), Smal (M), Stul (T), Dral (D), Sall (S), Nsil (N), Pstl (P), EcoRV (V), BspEl (I), Sacl (C). Symbols in parentheses indicate that the map is not complete for that particular enzyme. Symbols in (b) are numbered for multiple sites. 
Construction of bofC-lac $Z$ transcriptional fusions and measurement of $\boldsymbol{\beta}$-galactosidase activity. The 918 bp EcoRI$B a m \mathrm{HI}$ fragment from pSC63 was cloned into the EcoRIBamHI sites of plasmids pDG268 (Stragier et al., 1988) and pTKlac (Kenney \& Moran, 1987) (NB: the BamHI site is derived from the polylinker cloning sites of pSC63). The resulting subclones, pMG1 and pMG23, respectively, contained the $5^{\prime}$ region of bofC fused in front of the lac $Z$ gene of E. coli. pDG268, like pDG364 (see above), allows insertion of DNA (here the lacZ fusion) at the amyE locus by marker replacement, while pTKlac allows insertion of the lacZ fusion in the site defined by the cloned insert (i.e. the normal chromosomal position of the gene) through a Campbell-type single crossover recombination. Strain MG24 (amyE: : bofClacZ) was created by transforming cells (PY79) with linearized pMG1 and screening for Amy $\mathrm{Cm}^{\mathrm{R}}$ colonies. Strain MG196 (bofC: :bofC-lacZ) was created by transforming cells (PY79) with pMG23 followed by $\mathrm{Cm}^{\mathrm{R}}$ selection. $\beta$-Galactosidase activity was determined as described by Nicholson \& Setlow (1990).

\section{RESULTS}

\section{Identification of a locus, bofC, involved in the intercompartmental regulation of $\sigma^{k}$-directed gene expression}

As described in Methods we used a genetic screen to identify bof (bypass of forespore gene expression) alleles in the spoIVF (bof $B$ ) locus. Surprisingly, we identified one mutation (bofC1) that restored $\sigma^{\mathrm{K}}$-directed gene expression (as indicated by the $\mathrm{Pig}^{+}$phenotype) in a spollIG mutant (unable to produce $\sigma^{G}$ ), mapped near spolVF (7\% co-transformation linkage; Fig. 1) yet was not allelic. The bofC1 mutation then, defines a fourth locus, bofC, which together with $s p o I V B$, bof $A$ and spoIVF (bof $B$ ), is involved in the intercompartmental signal transduction pathway that activates $\sigma^{\mathrm{K}}$.
Since bofC1 was able to restore $\sigma^{\mathrm{K}}$-directed gene expression in a spolllG mutant we reasoned that it would be similar phenotypically to the $b$ of $A$ and $b o f B$ (spoIVFA) mutations. Both bof $A$ and $b o f B$ alleles restore substantial amounts of $\sigma^{\mathrm{K}}$-directed gene expression in spoIIIG cells but also allow premature expression of $\sigma^{\mathrm{K}}$. dependent genes since the requirement of the forespore signal for processing of pro- $\sigma^{\mathrm{K}}$ has been bypassed.

We introduced a gerE-lacZ fusion ( $g e r E$ is a member of the $\sigma^{\mathrm{K}}$ regulon; Cutting et al., 1989) by specialized transduction into isogenic strains containing the following alleles: $s p o^{+}$; spoIIIG $\Delta 1$; spolIIG $\Delta 1$ bofC1; and spoIIIG $\triangle 1$ bofB8. When sporulation was induced gerEdirected $\beta$-galactosidase synthesis in wild-type $\left(s p o^{+}\right)$ cells initiated 3.5-4h following induction and was essentially abolished in spoIIIG $\Delta 1$ cells (Fig. 2a). In spoIIIG $\triangle 1$ bofB8 cells gerE-lacZ expression initiated about 30-45 min prematurely. In contrast, gerE-directed $\beta$-galactosidase synthesis was significantly delayed in spoIIIG 1 bofC1 cells, initiating approximately $3 \mathrm{~h}$ later than in $s \mathrm{so}^{+}$cells and reaching a maximum level of activity almost $15 \mathrm{~h}$ after the initiation of sporulation. This delay was also observed using $l a c Z$ transcriptional fusions to two other members of the $\sigma^{\mathrm{K}}$ regulon, $\cot A$ and $\cot \mathrm{D}$ (data not shown).

Introduction of the bofC1 mutation into a spolllA53 strain also restored $\sigma^{\mathrm{K}}$ activation, although $\sigma^{\mathrm{K}}$-dependent gene expression started $2 \mathrm{~h}$, not $3 \mathrm{~h}$, later than in the wild-type strain (Fig. 2b). spoIIIA is an operon containing eight genes, transcribed by $\mathrm{E} \sigma^{\mathrm{E}}$, that is known to be involved in the activation of $\sigma^{\mathrm{G}}$ (Stragier, 1992). In contrast, the bofC1 mutation did not restore $\sigma^{\mathrm{K}}$-directed gene expression in strains carrying the mutations spoIVFB152 or spoIVCB23 (spoIVCB provides the $5^{\prime}$ end of the composite gene, $\operatorname{sig} K$, that encodes $\sigma^{\mathrm{K}}$ ).



Fig. 2. bofC1 bypasses the requirement of $\sigma^{\mathrm{G}}$ for $\sigma^{\mathrm{K}}$ activation and is a loss-of-function mutation. $\sigma^{\mathrm{K}}$ activity was monitored by measuring gerE-directed $\beta$-galactsidase synthesis at the indicated times after the induction of sporulation $\left(t_{0}\right)$. Strains were lysogenic for SP $\beta$ : : gerE-lacZ and only the relevant alleles are shown. (a) PY79 spo ${ }^{+}(\square), S^{+}$S500 spollIG $\triangle 1$

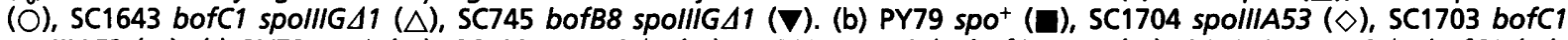

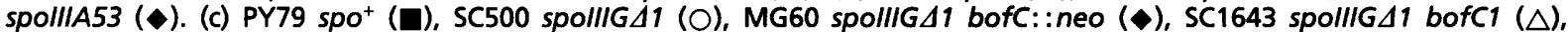
MG54 bofC::neo ( $\diamond)$, MG257 csbX::neo bofC1 (O). Background levels of $\beta$-galactosidase detected in spo cells containing no gerE-lacZ fusion have been subtracted. 


\section{Orf1}

Pst I

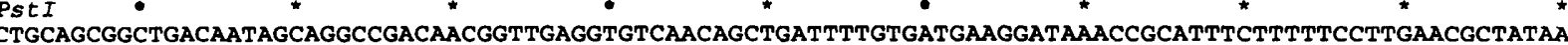

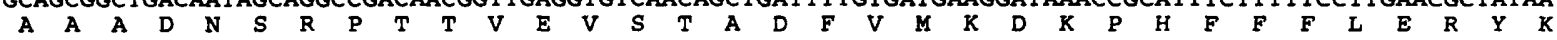

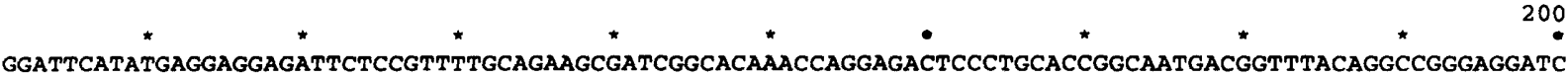
$\begin{array}{lllllllllllllllllllllllllllllllllll}D & S & Y & E & E & E & I & L & R & F & A & E & A & I & G & T & N & Q & E & T & P & C & T & G & N & D & G & L & Q & A & G & R & I\end{array}$

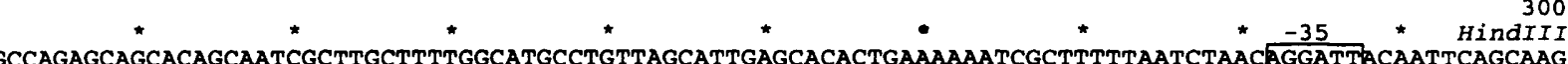
aAAAATCGCTTTTAATCTAACAgGATTACAATCAGCAAG

\section{Orf2 (csbX)}

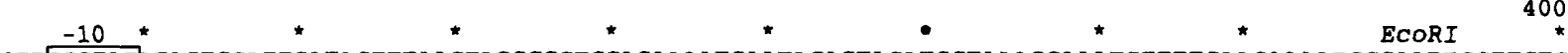
CTTGGTATATACTCCATTGATACTTTAAGTAGGCGGTGGAGAAAATGATACAGTACATGCTAAAGGAAATTTTTGAACAAAATCGGAATCCTTCTC $\begin{array}{llllllllllllllllll}M & N & \text { T } & \text { V } & \text { H } & \text { A } & \text { K } & \text { G } & \text { N } & \text { V } & \text { L } & \text { N } & \text { K } & \text { I } & \text { G } & I & P & S\end{array}$

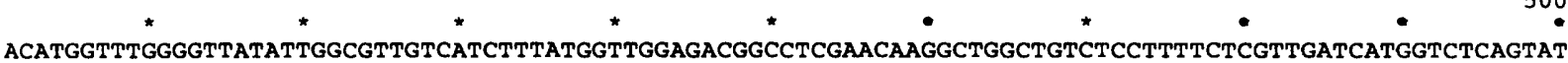



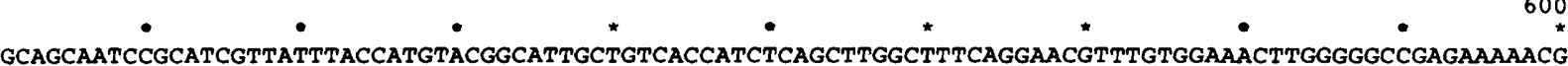

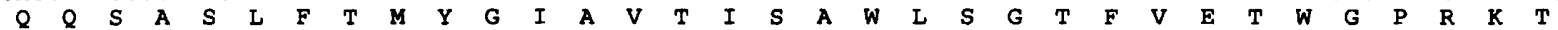

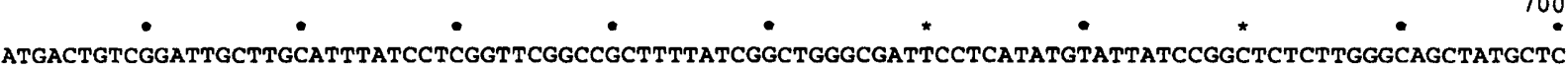
$\begin{array}{lllllllllllllllllllllllllllllllll}\text { M } & \text { T } & \text { V } & \text { G } & \text { L } & \text { L } & \text { A } & \text { F } & \text { I } & \text { L } & \text { G } & \text { S } & \text { A } & \text { A } & \text { F } & \text { I } & \text { G } & \text { W } & \text { A } & \text { I } & \text { P } & \text { H } & \text { M } & \text { Y } & \text { Y } & \text { P } & \text { A } & \text { L } & \text { L } & \text { G } & \text { S } & \text { Y } & \text { A }\end{array}$



800



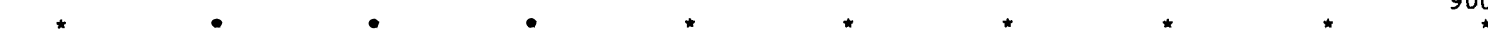
GTTTATGTTTACGTGCGGCCTTAACGTGCTCGGTCCGTTCTATTCCAGCTATGCAGTTCCGGCCTTTGGAGAAATCAATACGCTTTGGAGCGCTTTACTG

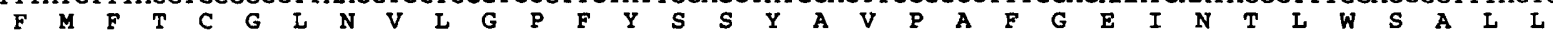

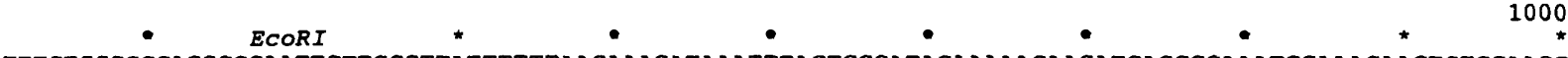
TTTGTGGCGGCAGGCGGATTCTTGCCTTATTTTTTAACAAAGATAAATTTACTCCGATACAAAAACAAGATCAGCCGAAATGGAAAGAACTGTCGAAGg

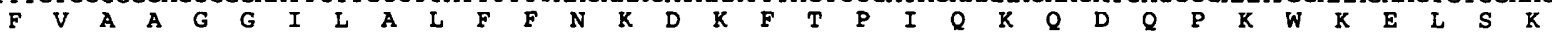

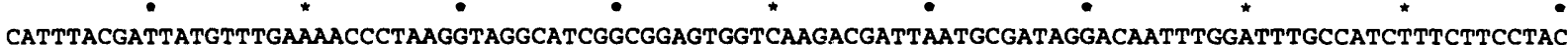

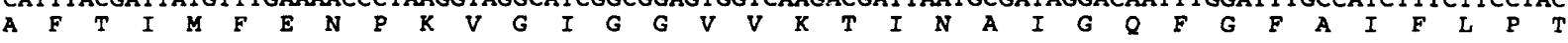



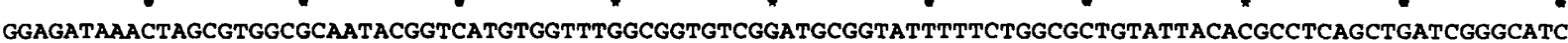

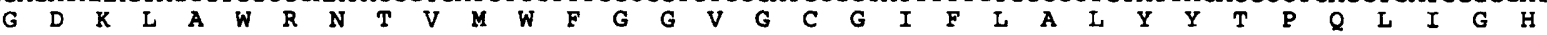

\section{0}

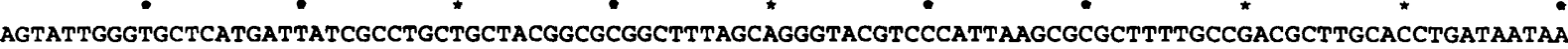

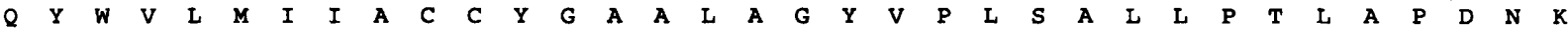



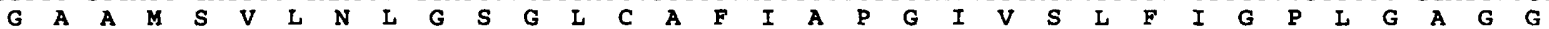

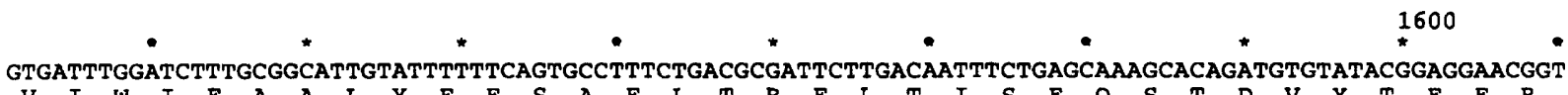

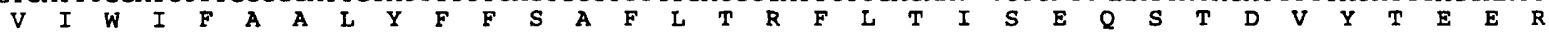

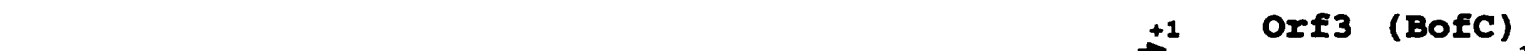

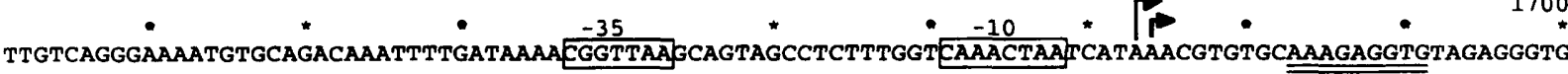

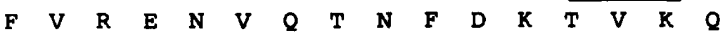

Fig. 3. For legend see opposite. 


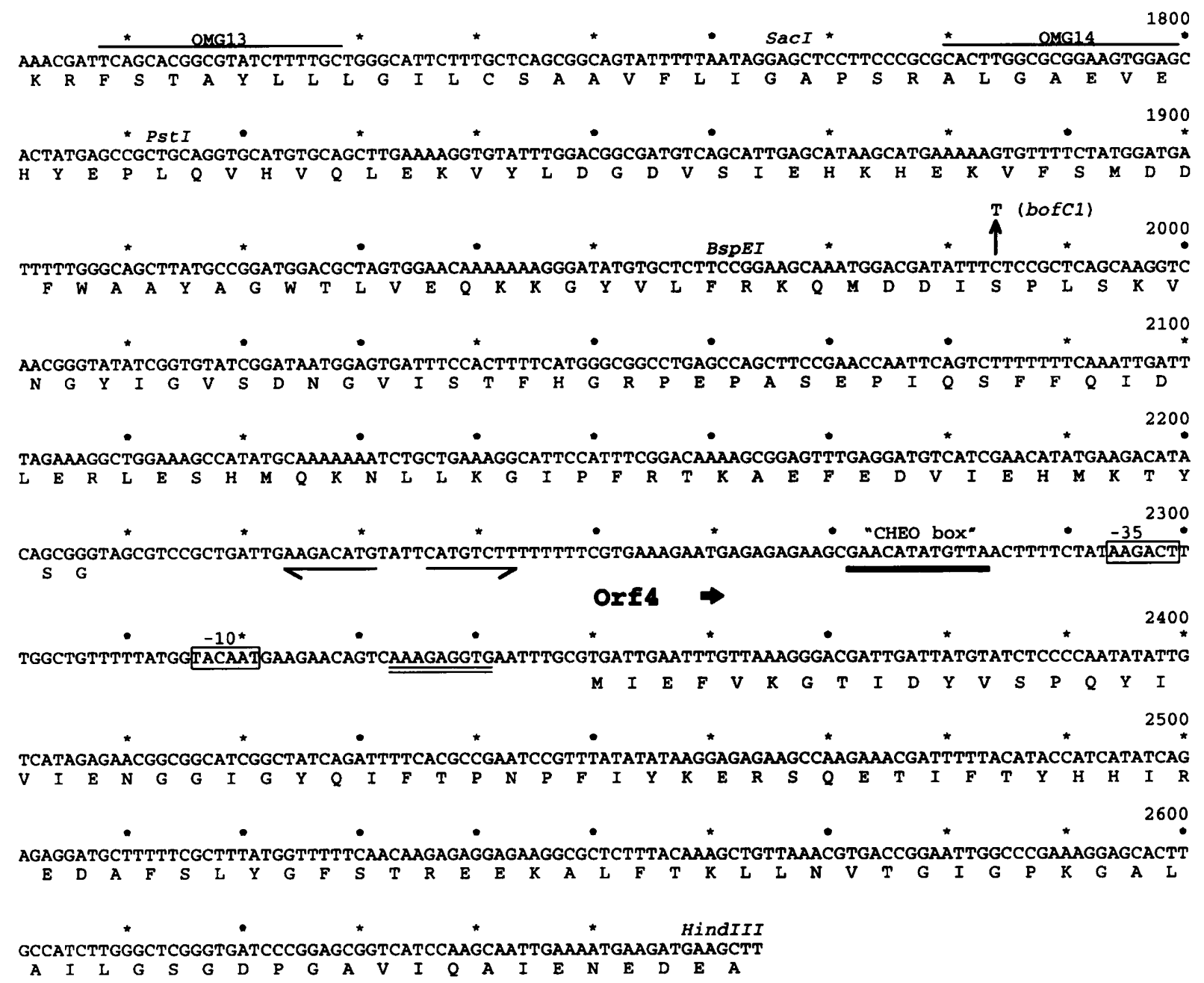

Fig. 3. Nucleotide sequence of the bofC region of the chromosome. The nucleotide sequence of the non-transcribed strand is shown together with potential coding regions. Putative ribosome-binding sites are doubly underlined and regions of dyad symmetry are underlined with arrows. The start point $(+1)$ and orientation of transcription of the bof $C$ gene is indicated by an arrow. Putative -10 and -35 promoter sequences for $\operatorname{cs} b X\left(\sigma^{B}\right)$, bofC $\left(\sigma^{\mathrm{F}} / \sigma^{\mathrm{G}}\right)$ and ORF4 $\left(\sigma^{A}\right)$ are boxed. OMG13 and OMG14 are the synthetic oligonucleotides used as primers for mapping the $5^{\prime}$ terminus of bofC mRNA. The figure also shows the 'Cheo Box' operator sequence upstream of ORF4, the bofC1 missense mutation and restriction sites used for subcloning and other manipulations described in the text.

As judged by phase-contrast microscopy sporulating cultures of spoIIIGA1 bofC1 mutant cells produced intact phase-grey spores which were released from the sporangial cell as 'sporelets', while sporulation in spolIIG $\Delta 1$ cells was blocked just after engulfment.

\section{Cloning and nucleotide sequence of the bofC region}

Genetic mapping placed bofC1 between the spoIVF and spoVB loci while fine-structure mapping using integrational plasmids placed bofC1 within a $0.89 \mathrm{~kb}$ SaclHindIII $_{(2)}$ fragment near the spoVB locus (see Fig. 1b).

We sequenced $2660 \mathrm{bp}$ of DNA beginning at the $H_{\text {indIII }}$ (2) site downstream of bofC, across the Sacl site to an upstream PstI site (Figs 1 and 3). We identified four potential ORFs in this region. Corresponding to the map position of bofC1 we identified a major ORF which would encode a polypeptide of 170 amino acid residues (19295 Da). This ORF was preceded by a putative ribosome-binding site and sequences that corresponded to the -35 (CGgtTAA) and -10 (CAAACTAA) consensus sequence of $\mathrm{E} \sigma^{\mathrm{F}}$ - and $\mathrm{E} \sigma^{\mathrm{G}}$-recognized promoters (Moran, 1993). Immediately following this ORF was a region of dyad symmetry followed by a stretch of $T$ residues that could function as a rho-independent transcriptional terminator. As will be shown later this ORF encodes the BofC polypeptide and is designated bofC in Fig. 3. BofC showed no significant homology to sequences in the GenBank, EMBL or NBRF databases. BofC did possess one interesting feature which may be of functional importance though, a potential signal sequence at its $\mathrm{N}$-terminus which could target and allow translocation of the polypeptide through a phospholipid membrane. 
Following bofC is the $5^{\prime}$ end of an ORF, designated ORF4, which extends to the HindIII ${ }_{(2)}$ site. This ORF is preceded by a putative ribosome-binding site and sequences (aaGACt and TAcAAT) that could correspond to the -35 and -10 consensus sequence of promoters recognized by the vegetative RNA polymerase, $\mathrm{E} \sigma^{\mathrm{A}}$ (Moran, 1993). The 105 codons of ORF4 we have identified would encode a polypeptide that has significant homology to the $5^{\prime}$ region of the $r u v A$ gene of $E$. coli. The $r u v A$ gene encodes a $22 \mathrm{kDa}$ polypeptide involved in homologous recombination that is induced by DNA damage as part of the SOS response and is regulated by the LexA protein (Shinagawa et al., 1988). Upstream of the putative -35 promoter sequence there is a sequence (GAAC- $\mathrm{N}_{4}$-GTTa) of high similarity to the 'Cheo Box' sequence (GAAC- $\mathrm{N}_{4}$-GTTC) that functions as an operator in controlling the expression of din genes in B. subtilis. din (DNA-damage-inducible) genes are regulated as a response to DNA damage by the DinR protein in a manner similar to LexA-controlled genes in E. coli (Cheo et al., 1991). Earlier work has shown that the UV-sensitive mutation, recB2, maps in the pheA-nic region of the chromosome (Hoch \& Anagnostopoulos, 1970).

Upstream of bofC are two further ORFs, ORF1 and ORF2. Only the 3 ' end of ORF1, encoding 90 amino acid residues, has been sequenced but this would terminate at nucleotide 272 of Fig. 3. ORF2 contains 434 codons that could encode a polypeptide of $47714 \mathrm{Da}$. In other work (Gomez \& Cutting, 1997) we have found that this ORF is under the control of $\sigma^{\mathbf{B}}$ during stationary-phase growth and we have named it $c s b X$ (controlled by sigma B).

To identify the bofC1 mutation in this region we used two oligonucleotide primers to amplify the region of DNA containing virtually the entire coding region of bofC (ORF3) from strain SC1643 containing the bofC1 allele. The cloned DNA was sequenced on both strands and one base change corresponding to $\mathrm{C}$ to $\mathrm{T}$ transition (nucleotide 1984 of Fig. 3) was identified converting the serine codon at position 96 to a phenylalanine codon.

\section{bofC1 is a loss-of-function mutation}

We constructed a bofC1 spoIIIG ${ }^{+}$strain (MG257) and found that during sporulation the bofC1 mutation caused no impairment of sporulation efficiency or the production of heat resistant spores (results not shown). The bofC1 allele, being a missense suppressor, may not necessarily affect the function of BofC in the presence of $\sigma^{\mathrm{G}}$. Therefore, to determine the requirements of BofC for spore formation we created an insertional mutation in the bofC ORF (see Fig. 1 and Methods). Although this was not a complete knockout mutation we expected, at most, no more than half of the BofC polypeptide to be synthesized in this construct. We then compared the phenotypes associated with the bofC::neo (strain MG54) and bofC1 (strain MG257) mutations. The bofC: : neo strain was $\mathrm{Spo}^{+}$and indistinguishable from the congenic strains PY79 $\left(s p o^{+}\right)$and MG257 (bofC1), and it produced normal levels of heat-resistant spores (results not shown). We measured $\sigma^{\mathrm{K}}$-directed gene expression (using SPBgerE-lacZ) in these strains and found that there was a noticeable difference in the kinetics of gene expression, compared with the wildtype strain, PY79. Specifically, there was a slight delay and a reduction in maximum levels of gerE-directed $\beta$ galactosidase synthesis in both mutants (Fig. 2c).

Since the bofC: : neo and bofC1 mutants were similar phenotypically we wondered if the BofC phenotype was caused by the absence of the BofC protein. To address this we introduced the bofC:: neo construct into spoIIIG 11 cells (strain MG60) and measured gerE-lacZ expression (Fig. 2c). In these cells significant levels of $\sigma^{\mathrm{K}}$ directed gene expression were restored although, as was the case with bofC1, there was a substantial delay in the initiation of gene expression $(\sim 3 \mathrm{~h})$. Examination of the double mutant revealed that spore formation had advanced to stage IV-V with the production of phasegrey sporelets as was found with the bofC1 spoIIIG $\Delta 1$ mutant.

\section{bofC is monocistronic}

To determine the transcriptional borders of bofC we employed a method routinely used in $B$. subtilis. Since the BofC phenotype is due to loss of function of the bofC gene product we reasoned that a plasmid containing neither the transcription start nor termination signals would, upon a Campbell-type integration into the chromosome in spollIG $\Delta 1$ cells, disrupt the bofC gene resulting in a $\mathrm{Pig}^{+}$phenotype. We used the plasmids pSC60, pSC61, pSG63, pMG7 and pMG28, each carrying a segment of the DNA covering part of bofC (see Fig. 1 and Methods). These plasmids contain the cat gene, which allows insertion of the plasmid DNA into the chromosomal region (defined by the cloned insert) by selection for $\mathrm{Cm}^{\mathrm{R}}$. When pSC60, pSC61, pSC63 and pMG7 were introduced into spoIIIG 11 cells a $\mathrm{Pig}^{-}$ $\left(\right.$ SpoIIIG $\left.{ }^{-}\right)$phenotype resulted, showing that the transcriptional start (pSC63, pMG7) and termination signals (pSC60, pSC61) must be contained within the cloned DNA in these plasmids. pMG28, however, containing DNA internal to the bofC ORF produced a $\mathrm{Pig}^{+}$ phenotype, which must have resulted from disruption and inactivation of bofC. In each cross, the Pig phenotype was confirmed both by phase-contrast microscopy and by measuring gerE-lacZ expression in cells lysogenized with $S P \beta:$ : gerE-lacZ (data not shown). These results imply that the bofC locus lies between the $E_{\text {coRI }}$ and HindIII $(2)$ sites (the upstream and downstream boundaries of the $B$. subtilis DNA insert in pMG7 and pSC60/pSC61, respectively, as shown in Fig. 1) located at positions 917 and 2659, respectively, of Fig. 3.

To further define the bofC operon we constructed a merodiploid for trans complementation analysis. Two synthetic oligonucleotide primers were used to amplify 




Fig. 4. bofC-lacZ expression. $(a, b)$ bofC-directed $\beta$-galactosidase synthesis was determined at the indicated times following the induction of sporulation $\left(t_{0}\right)$. All strains contained a bofC-lac $Z$ transcriptional fusion introduced at the amyE locus by DNA-mediated transformation and with the exception of the indicated allele were isogenic. (a) PY79 spo


spollGB55 ( $\triangle$ ), SC1159 spollAC1 ( $\square$ ). Background levels of $\beta$-galactosidase observed in spo ${ }^{+}$cells containing no bofC-lacZ fusion have been subtracted. (c) bofC-directed $\beta$-galactosidase synthesis was determined in spollIG $\Delta 1$ cells containing the bofC-lacZ fusion at the amyE locus (strain MG103) and either pSDA4 (Pspac-IIAC) or pDG298 (Pspac-IIIG). Cultures were grown in $2 \times \mathrm{YT}$ medium with phleomycin $\left(0.1 \mu \mathrm{g} \mathrm{ml}^{-1}\right)$; at an $\mathrm{OD}_{600}$ of 0.3 the culture was split and IPTG added to one portion (final concentration $1 \mathrm{mM}$ ) and growth of both cultures continued. Samples were removed and assayed for $\beta$ galactosidase activity at the indicated times after IPTG induction. $\diamond$, pSDA4 without IPTG; $\diamond$, pSDA4 plus IPTG; $\nabla$, pDG298 without IPTG; $\nabla$, pDG298 plus IPTG.

DNA covering the $b$ ofC ORF and an additional 205 bp upstream of the bofC start codon and $236 \mathrm{bp}$ downstream of the bofC translational stop signal. We predicted that this segment (nt 1493-2446 of Fig. 3) would contain the putative bofC regulatory elements but separate it from other possible coding regions (ORF2 and ORF4). The amplified DNA product was cloned and introduced at the amyE locus of cells containing bofC1 spoIIIGA1 (SC1643) or bofC::neo spoIIIGA1 (MG60). The phenotype of the resulting transformants was $\mathrm{Pig}^{-}$, demonstrating in trans complementation (confirmed by analysis of gerE-directed $\beta$-galactosidase synthesis; results not shown) and the recessive nature of the bofC1 and bofC: : neo alleles.

\section{bofC expression}

To study the expression of $b$ of $C$ during sporulation we constructed a transcriptional fusion of $b$ of $C$ to the $l a c Z$ gene of E. coli at the $a m y E$ locus. To monitor bofC-lacZ expression cells were induced to sporulate and sampled for $\beta$-galactosidase activity at appropriate times following the induction of spore formation. Fig. 4 shows that $b$ of $C$-directed $\beta$-galactosidase synthesis commenced at about $1 \mathrm{~h}\left(t_{1}\right)$ after the start of sporulation and produced two clearly identifiable temporal phases of expression. The first phase, starting at $t_{1}$ peaked at $t_{2}$ and following a brief decline resumed with the second phase at $t_{2 \cdot 5}$, which continued to elevate the level of bof $C$-directed $\beta$-galactosidase synthesis to a maximum at $t_{5}$.
To determine the dependence of bofC expression on the products of other spo genes we introduced, by DNAmediated transformation, the $b$ ofC-lac $Z$ fusion into a collection of spo mutants (all congenic with the $s p o^{+}$ strain PY79). bofC-directed $\beta$-galactosidase synthesis was determined at various times during sporulation in parallel with an isogenic $s \mathrm{so}^{+}$strain containing the bofC-lacZ fusion (strain MG24). The pattern of bofC expression from some typical experiments is shown in Fig. 4(a, b). bofC expression was essentially abolished in a spoIIAC mutant (unable to produce $\sigma^{\mathrm{F}}$ ). In contrast, the spoIID, spoll $G$ and spollIG mutations (which impair the production of active $\sigma^{\mathrm{G}}$ ) affected the 'biphasic' pattern of bofC-directed $\beta$-galactosidase synthesis by reducing the second phase of bofC-lacZ expression. In addition, the spoIID66 mutation caused a noticeable reduction in the first phase of expression while the spollG55 mutation caused an elevation in the first phase. The spolVCB mutant, though, did not have impaired bofC expression but showed an elevation in the second phase of expression.

As further proof that bofC is controlled by both $\sigma^{\mathrm{F}}$ and $\sigma^{G}$ we induced the synthesis of an active form of either $\sigma^{F}$ or $\sigma^{G}$ during vegetative growth and measured bofCdirected $\beta$-galactosidase synthesis at appropriate times thereafter. For these experiments we used two autonomously replicating plasmids, pSDA4 (Shazand et al., 1995) and pDG298 (Sun et al., 1989) to facilitate induction of $\sigma^{\mathrm{F}}$ and $\sigma^{\mathrm{G}}$ respectively. These plasmids contain the structural genes of $\sigma^{\mathrm{F}}$ (spoIIAC; pSDA4) and $\sigma^{\mathrm{G}}$ (spoIIIG; pDG298) fused downstream, and under the 


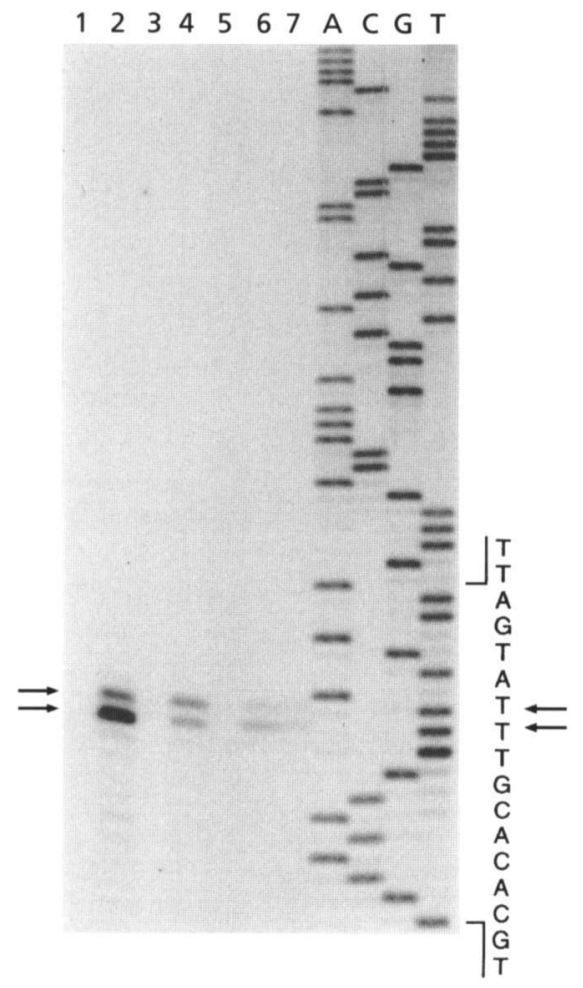

Fig. 5. Mapping the $5^{\prime}$ terminus of bofC mRNA. (a) The transcriptional start point of bofC was determined by primer extension using the primer OMG13. For $\sigma^{F} / \sigma^{G}$-induced cultures (lanes 1-4), total RNA was prepared from SC500 (spollIGA1) cells growing exponentially and containing either pSDA4 or pDG298 (which allow expression of $\sigma^{F}$ or $\sigma^{G}$, respectively, after IPTG induction). Following addition of IPTG (1 $\mathrm{mM}$ ) total RNA was collected and used for CDNA synthesis using labelled OMG13. Lanes: 1, pSDA4 without IPTG; 2, pSDA4 plus IPTG; 3, pDG298 without IPTG; 4, pDG298 plus IPTG. For sporulating cultures (lanes 5-7), RNA was prepared from spo+ cells (PY79) at $0 \mathrm{~h}$ (lane 5), $2.5 \mathrm{~h}$ (lane 6 ) and $5 \mathrm{~h}$ (lane 7) after the initiation of spore formation. The nucleotide sequencing ladder shown on the right was generated using [ $\gamma$-32P]ATP-labelled OMG13 and a plasmid template containing bofC. An extension product with the same $5^{\prime}$ termini was obtained using the primer OMG14 for bofC (results not shown).

control of, the IPTG-inducible spac promoter. Fig. 4(c) shows that addition of IPTG to vegetatively growing spollIG 11 cells containing pSDA4 or pDG298 resulted in significant induction of $b o f C$-directed $\beta$-galactosidase synthesis.

As a definitive characterization of $b$ ofC regulation we defined the $5^{\prime}$ terminus of bofC mRNA by primer extension analysis, using the primers OMG13 and OMG14 (shown in Fig. 3) and total RNA prepared from (1) exponentially growing spollIG $\Delta 1$ cells in which either $\sigma^{\mathrm{F}}$ or $\sigma^{\mathrm{G}}$ was induced or (2) sporulating cells $\left(s p o^{+}\right)$. As shown in Fig. 5 , in vegetatively growing cells producing either $\sigma^{\mathrm{F}}$ or $\sigma^{\mathrm{G}}$, a transcript was identified that started $25 \mathrm{bp}$ upstream of the bofC ORF. The same transcript was observed in sporulating cell extracts at 2.5 and $5 \mathrm{~h}$ but not at $0 \mathrm{~h}$.

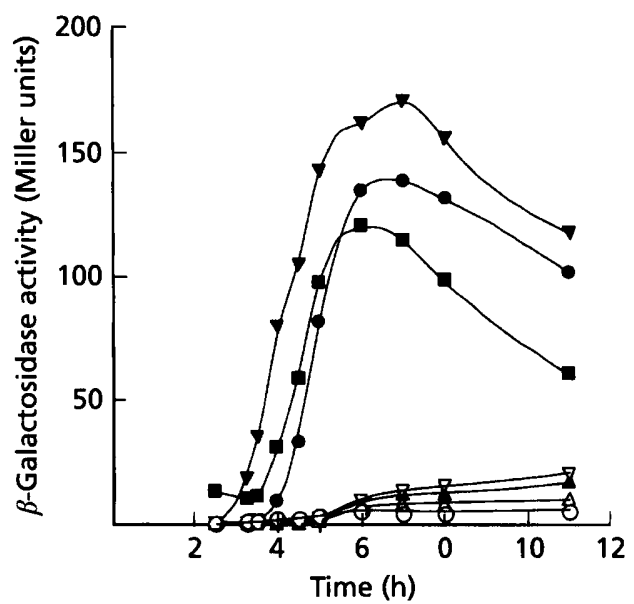

Fig. 6. bofC mutations do not bypass the requirement of SpolVB for $\sigma^{\mathrm{K}}$ activation. The indicated strains, lysogenic for $S P \beta:$ :gerE-lacZ, were induced to sporulate and gerE-directed $\beta$ galactosidase synthesis was measured at the indicated times following the initiation of sporulation $\left(t_{0}\right)$. Other than the indicated allele all strains were isogenic: PY79 $\mathrm{spo}^{+}(\square)$, SC500 spollIGA1 (O), SC745 spollIGA1 bofB8 ( $)$, MG101 spolvBA: :spc ( $\triangle$ ), MG291 spolvBA::spc bofC1 (A), MG117 spolVBA: : spc bofC: : neo ( $\nabla)$, MG126 spolVBA: :spc bofB8 (O). Background levels of $\beta$-galactosidase observed in spo $^{+}$cells containing no fusion have been subtracted.

\section{bofC mutations do not bypass the requirement of SpolVB for $\sigma^{\mathrm{K}}$ activation}

Since bofC1 bypasses the requirement of spoIIIG for $\sigma^{\mathrm{K}}$ activation it should likewise bypass spoIVB since this gene is $\sigma^{G}$-controlled. In recent work, however, we have found that $s p o I V B$ is transcribed at very low levels by $\mathrm{E} \sigma^{\mathrm{F}}$ (Gomez \& Cutting, 1996). We introduced the bofC1 or bofC: :neo alleles into a spoIVBA: :spc insertional mutant and lysogenized cells with SP $\beta:$ :gerE-lacZ and measured $\beta$-galactosidase activity during sporulation. As a control, we also examined a spoIVBA: :spc bof $B 8$ double mutant (MG126) in which the requirement of SpoIVB in the $\sigma^{\mathrm{K}}$ checkpoint is bypassed. Our results (Fig. 6) show that the bofC alleles did not restore $\sigma^{\mathrm{K}}$ directed gene expression in the spoIVB mutant whereas bofB8 restored significant levels of gerE-lacZ expression. Interestingly, gerE-lacZ expression in the bofB8 spoIVBA: :spc cells was approximately $1 \mathrm{~h}$ later than the premature expression seen in spoIIIG $\Delta 1$ bof $B 8$ cells.

\section{$\operatorname{cs} b X$ and bofC could be cotranscribed during stationary phase}

We wondered whether bofC could be cotranscribed from the upstream $\sigma^{\mathbf{B}}$-dependent $c s b X$ promoter, since as mentioned earlier, no transcriptional terminator follows $c s b X$. To address this we first constucted a bofC-lacZ fusion contained at the bofC locus (bofC: : bofC-lacZ) as opposed to the amyE locus (see Methods). In this construct bofC expression could be 


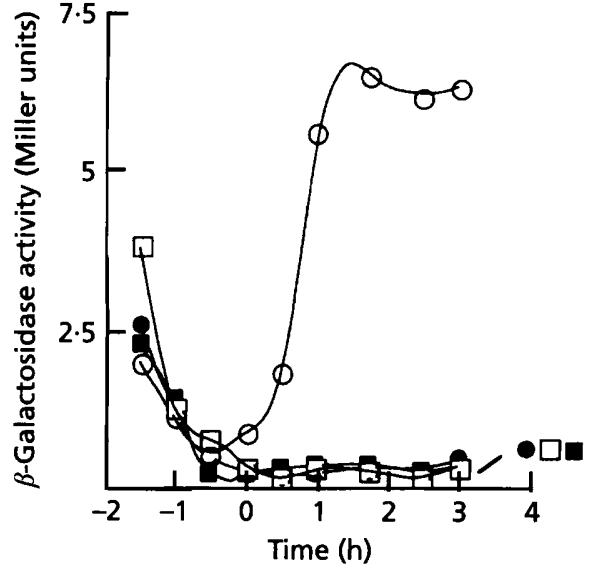

Fig. 7. $c s b X$ and bof $C$ are transcribed during the stationary phase. bofC-directed $\beta$-galactosidase synthesis was measured before and after the end of exponential growth $\left(t_{0}\right)$ in LB supplemented with glucose $(5 \%)$ and glutamine $(0.2 \%)$. $\square$, amyE::bofC-lacZ (MG24); O, bofC::bofC-lacZ (MG196); D, sigB314 amyE::bofC-lacZ (MG242); 0 , sigB314 bofC: : bofC-lacZ (MG243). Background levels of $\beta$-galactosidase observed in $\mathrm{spo}^{+}$cells containing no fusion have been subtracted.

controlled not only by the $\sigma^{\mathrm{F}} / \sigma^{\mathrm{G}}$-dependent promoter but also by any other regulatory elements that might exist upstream of $b$ ofC (including the $c s b X$ promoter). During sporulation we found that $b o f C$ expression was identical whether bofC-directed $\beta$-galactosidase synthesis was driven by bofC-lac $Z$ at the bofC locus or at amyE (results not shown). However, when bofC expression was measured during growth in LB supplemented with glucose and glutamine (i.e. under conditions where sporulation is catabolite repressed (Schaeffer et al., 1965) we found that bofC was expressed at the end of exponential phase when bofC-lacZ was placed at the bofC locus but not when bof $C$ was placed at the amyE locus (Fig. 7). Moreover, this expression was abolished in a sigB314 mutant, showing that this stationary-phase expression was under $\sigma^{\mathrm{B}}$ control.

\section{DISCUSSION}

The $\sigma^{\mathrm{K}}$ checkpoint provides an elegant device for regulating $\sigma^{\mathrm{K}}$-directed gene expression during sporulation. Four developmental proteins facilitate this: SpoIVFA, SpoIVFB, BofA and SpoIVB. The first three are the most likely candidates for the processing complex that cleaves pro- $\sigma^{\mathrm{K}}$ to its mature form in the mother cell compartment. SpoIVB's function is to signal processing by transiting the forespore membranes and interacting directly, or indirectly, with the BofA-SpoIVFASpoIVFB complex.

Our results clearly show that the bofC gene product is also involved in the $\sigma^{\mathrm{K}}$ checkpoint. The bofC1 or bofC: : neo alleles show similarities to the bof $A$ and $b$ of $B$ suppressor mutations. First, bofC1 restores $\sigma^{\mathrm{K}_{-}}$ directed gene expression in a mutant unable to synthesize $\sigma^{G}$ and so uncouples the requirement of forespore gene expression for pro- $\sigma^{\mathbf{K}}$ activation. Second, bofC1 bypasses a spolllA mutant whose gene products are required for $\sigma^{\mathrm{G}}$ activation. Interestingly, $\sigma^{\mathrm{K}}$-directed gene expression was turned on earlier in a bofC1 spoIIIA53 mutant than in a bofC1 spollIG $\Delta 1$ mutant. Possibly, in a spoIIIA53 mutant a low level of active $\sigma^{\mathrm{G}}$ could be produced, explaining why $\sigma^{K}$-directed gene expression was turned on earlier than in a spollIG $\Delta 1$ cells. Third, the bofC1 (or bofC: : neo) mutation confers an advanced sporulation phenotype upon spoIIIG $\Delta 1$ (or spoIIIA53) cells which is attributed to the aberrant synthesis and assembly of coat proteins onto the immature forespore in the absence of $\sigma^{\mathrm{G}}$-dependent gene expression (Cutting et al., 1990). Finally, insertional inactivation of $b$ of $C$ produces a Bof phenotype showing that loss of function of the bofC gene product is required for suppression [this is true also for null mutations in the bof $A$ and bof $B$ (spolvFA) genes]. Thus, the bofC gene product would most likely act negatively in the $\sigma^{\mathrm{K}}$ checkpoint, which is also true for the bof $A$ and $b o f B$ mutations.

The bofC mutations are, however, distinct from bof $A$ and bof $B$ in three crucial respects: (1) the compartment in which the gene defined by the mutation is expressed, (2) timing of $\sigma^{\mathrm{K}}$ activation in bof spolIIG $\Delta 1$ strains and (3) their ability to bypass the requirement of SpoIVB for intercompartmental signalling. Thus, the similarity in phenotype produced by the bofC alleles with that produced by the bof $A$ and $b o f B$ mutations must be considered superficial. These differences are discussed further below.

\section{bofC is forespore expressed}

The requirements for bofC transcription are most similar to the prespore-expressed genes $g p r$ and $d a c F$, which are controlled first by $\sigma^{\mathrm{F}}$ and then by $\sigma^{\mathrm{G}}$ (Partridge \& Errington, 1993). Most indicative is the 'biphasic' pattern of gene expression seen as two peaks of activity representing the periods where first $\sigma^{\mathrm{F}}$ and then $\sigma^{\mathrm{G}}$ is functional in the prespore. For $g p r / d a c F$ transcription, as with bofC, the spollAC gene is absolutely required since this gene encodes $\sigma^{\mathrm{F}}$, essential not only for the first phase of prespore gene expression but also for transcription of spollIG, which encodes $\sigma^{\mathrm{G}}$, the sigma factor directing the second phase of compartmentalized gene expression. Mutations blocking $\sigma^{\mathbf{F}}$ - or $\sigma^{\mathrm{G}}$-directed gene expression have been well documented and can be used to define whether a gene is forespore or mother cell expressed (Partridge \& Errington, 1993; Stragier, 1992). Thus, the spollG and spoIID mutants block only the second, $\sigma^{\mathrm{G}}$-controlled, phase of bofC expression since these genes encode proteins required for activating $\sigma^{G}$ in the forespore chamber. Likewise, a spoIVCB mutant did not impair bofC expression since this gene encodes pro$\sigma^{\mathrm{K}}$, which is required only for the mother cell programme of gene expression. Together, the temporal 'biphasic' pattern of gene expression and genetic 
dependence are diagnostic of a $\mathrm{E} \sigma^{\mathrm{F}}$-controlled gene expressed in the prespore chamber (beginning at $t_{1}$ ), which is later controlled, following engulfment, by $\mathrm{E}^{\mathrm{G}}$ (from $t_{2 \cdot 5}$ onwards). Supporting dual $\sigma^{\mathrm{F}} / \sigma^{\mathrm{G}}$ control we have shown also that $b$ of $C$ expression can be artificially induced in vegetatively growing cells by induction of $\sigma^{\mathrm{F}}$ or $\sigma^{\mathrm{G}}$ and we have mapped the $5^{\prime}$ terminus of bofC mRNA, placing it downstream of a putative $\sigma^{\mathrm{F}} / \sigma^{\mathrm{G}}$ recognized promoter.

In contrast, the bof $A$ and spolvF (bof $B$ ) genes are expressed beginning at $t_{1}$ in the mother cell chamber under the control of $\mathrm{E}^{\mathrm{E}}$ (Cutting et al., 1991b; Ricca et al., 1992). The spatial localization of bofC, spolvF and bof $A$ suggests that their gene products may act at different steps and use different mechanisms in the intercompartmental signal transduction pathway leading to $\sigma^{\mathrm{K}}$ activation.

\section{Timing of $\sigma^{\mathrm{k}}$ activation in SpollIG $\Delta 1$ cells}

Both the bofC1 and bofC: : neo mutations restored, at least partially, $\sigma^{\mathrm{K}}$-directed gene expression in strains unable to produce active $\sigma^{\mathrm{G}}$ (and presumably processing of pro- $\sigma^{\mathrm{K}}$ ) and this phenotype is well documented for the bof $A$ and bof $B$ mutations (Cutting et al., 1990). However, in one important respect the bofC alleles differ and this is in the timing of $\sigma^{\mathrm{K}}$-directed gene expression. bof $A /$ bof $B$ mutations allow premature processing $\left(t_{3.5}\right.$, approximately $30 \mathrm{~min}$ early) of pro- $\sigma^{\mathrm{K}}$ since SpoIVFB is constitutively active, presumably because the inhibitory action of SpoIVFA/BofA on SpoIVFB is relieved. In such strains then, as soon as pro$\sigma^{\mathrm{K}}$ is synthesized it is promptly cleaved. Interestingly, pro- $\sigma^{\mathrm{K}}$ is actually synthesized approximately $60 \mathrm{~min}$ prior to processing $\left(t_{3}\right)$, yet the earliest possible time at which cleavage can occur is $30 \mathrm{~min}$ after synthesis of pro- $\sigma^{\mathrm{K}}\left(t_{3.5}\right)$. This delay in processing, even when SpoIVFB is constitutively active, has been attributed to the time required for the putative processing complex to assemble into the outer forespore membranes (Gomez et $a l ., 1995)$. In contrast, the bofC mutations introduced a substantial delay of about $3 \mathrm{~h}$ before $\sigma^{\mathrm{K}}$-directed gene expression commenced $\left(t_{7-8}\right)$. This delayed $\sigma^{\mathrm{K}}$-dependent gene expression implies that the bofC mutations (or the absence of BofC) do not facilitate constitutive activity of SpoIVFB.

\section{BofC does not act ahead of SpolVB}

Since SpoIVFB is constitutively active in $b o f A$ and $b o f B$ mutants, pro- $\sigma^{\mathrm{K}}$ processing commences in the absence of any signal (SpoIVB) from the forespore. Accordingly, a $b$ of $A$ or $b$ of $B$ mutation will restore $\sigma^{\mathrm{K}}$-dependent gene expression in spollIG or spoIVB mutant strains. In contrast, bofC mutations bypass the requirement of $\sigma^{G}$ for $\sigma^{\mathrm{K}}$ activation but do not bypass mutations in the $s p o I V B$ gene. In other work we have found that spolvB expression is controlled not only by $\mathrm{E} \sigma^{\mathrm{G}}$ but also by $\mathrm{E} \sigma^{\mathrm{F}}$ (Gomez \& Cutting, 1996) and that in a spollIG mutant SpoIVB is still synthesized at very low levels, which are not enough to trigger $\sigma^{\mathrm{K}}$ activation in the mother cell. That spolvB can be transcribed by both $\mathrm{E} \sigma^{\mathrm{F}}$ and $\mathrm{E} \sigma^{\mathrm{G}}$ provides a hint about how the BofC phenotype is produced. In the absence of active $\sigma^{\mathrm{G}}$ (due to a null mutation in spoIIIG or spoIIIA) $\sigma^{\mathrm{F}}$-directed expression of SpoIVB would be sufficient to trigger $\sigma^{\mathrm{K}}$ activation, albeit delayed, but only if BofC is absent. Thus we conclude that BofC is a negative regulator, and that its absence compensates for the reduction in SpoIVB production in strains unable to produce active $\sigma^{\mathrm{G}}$. bofC mutations then, can not be considered true bof alleles since they do not uncouple the forespore and mother cell programmes of gene expression.

A simple explanation for BofC's function could be repression of $s p o I V B$ transcription. We have explored this possibility and found that a $b o f C$ mutation does not enhance spoIVB-lacZ expression in a spoIIIG mutant (data not shown). We are left, then, with BofC as a negative regulator of SpoIVB activity or function.

Four mechanisms for how BofC and SpoIVB interact can be proposed. First, BofC could be directly involved in the assembly and translocation of SpoIVB through the forespore membrane(s). Second, BofC could inhibit a 'hypothetical' enzymic activity of SpoIVB, probably by direct protein-protein interaction. Third, BofC could be involved in the proteolytic turnover of SpoIVB. Finally, BofC could prevent or block the proposed interaction of SpoIVB with the BofA-SpoIVFA-SpoIVFB processing complex in the outer forespore membranes.

Although our work clearly shows that BofC could negatively regulate SpoIVB function and that $b$ ofC must be considered a component of the $\sigma^{\mathrm{K}}$ checkpoint, no obvious function (which is attributed to other checkpoint genes) can be associated with bofC.

Another surprising finding was the difference in timing of $\sigma^{\mathrm{K}}$-directed gene expression in spoIIIG $\Delta 1$ bof $B 8$ or spoIVBA: :spc bofB8 cells. $\sigma^{\mathrm{K}}$ first appeared active at $t_{3}$ in spoIIIG $\triangle 1$ bofB8 cells while in spoIVBA: :spc bof $B 8$ cells $\sigma^{\mathrm{K}}$-directed gene expression commenced some $60 \mathrm{~min}$ later, and about $30 \mathrm{~min}$ later than in $s p o^{+}$cells. Previous work has shown that the bofB (spoIVFB) alleles allow constitutive processing of pro- $\sigma^{\mathrm{K}}$ and premature $\sigma^{\mathrm{K}}$-directed gene expression (Cutting et al., 1990; Lu et al., 1990). Here we find that in a spolVB mutant this does not occur. We reason that the membrane-bound processing complex consisting of BofA, SpoIVFB and the mutant form of SpoIVFA (encoded by bof $B 8$ ) could still be responsive to the low levels of $\sigma^{\mathbf{F}}$-produced SpoIVB in spollIG $\Delta 1$ cells, allowing premature signalling and processing of pro- $\sigma^{\mathrm{K}}$.

\section{The bofC transcriptional unit}

Although our work clearly suggests that bofC is monocistronic during development we present evidence suggesting that bofC could be transcribed by readthrough from the upstream gene $c s b X$ in stationaryphase conditions, when sporulation is repressed and in a 
$\sigma^{\mathrm{B}}$-dependent manner. The physiological significance of this probable read-through transcription is, for now, unclear, but it is unlikely that the bofC cistron of the $c s b X-b o f C$ transcript is actually translated. Examination of the nucleotide sequence shows that there exists a region centred approximately $-43 \mathrm{nt}$ from the bofC start codon, that could base-pair with the bofC ribosome-binding site (centred at -11) and block its availability to ribosomes. The sporulation transcript starts at $-25 \mathrm{nt}$ from the bofC start codon and therefore could not form any secondary structure. A similar situation has been described for the spoIIIG gene, which is initially cotranscribed with the spollG operon but translation is prevented by a region of dyad symmetry separating the spollG and spolllG cistrons (Stragier, 1992).

\section{ACKNOWLEDGEMENTS}

We thank Patrick Stragier for his invaluable advice and comments and Ting Ting Wu and Grace Lee for their contributions to this work.

S.C. is a recipient of a Junior Faculty Research Award from the American Cancer Society (JFRA-514) and M.G. a recipient of a Fulbright Postdoctoral Fellowship from the Spanish Ministerio de Educacion y Ciencia. This work was supported by NIH grant GM49206 to S. C.

\section{REFERENCES}

Cheo, D. L., Bayles, K. W. \& Yasbin, R. E. (1991). Cloning and characterization of DNA damage-inducible promoter regions from Bacillus subtilis. J Bacteriol 173, 1696-1703.

Cutting, S. M. \& Vander-Horn, P. B. (1990). Genetic analysis. In Molecular Biological Methods for Bacillus, pp. 27-74. Edited by C. R. Harwood \& S. M. Cutting. Chichester: John Wiley.

Cutting, S., Panzer, S. \& Losick, R. (1989). Regulatory studies on the promoter for a gene governing synthesis and assembly of the spore coat in Bacillus subtilis. J Mol Biol 107, 393-404.

Cutting, S., Oke, V., Driks, A., Losick, R., Lu, S. \& Kroos, L. (1990). A forespore checkpoint for mother cell gene expression during development in B. subtilis. Cell 62, 239-250.

Cutting, S., Driks, A., Schmidt, R., Kunkel, B. \& Losick, R. (1991a). Forespore-specific transcription of a gene in the signal transduction pathway that governs pro- $\sigma^{\mathrm{K}}$ processing in Bacillus subtilis. Genes Dev 5, 456-466.

Cutting, S., Roels, S. \& Losick, R. (1991b). Sporulation operon spoIVF and the characterization of mutations that uncouple mother-cell from forespore gene expression in Bacillus subtilis. $J$ Mol Biol 221, 1237-1256.

Errington, J. (1993). Bacillus subtilis sporulation: regulation of gene expression and control of morphogenesis. Microbiol Rev 57, $1-33$.

Gomez, M. \& Cutting, S. M. (1996). Expression of the Bacillus subtilis spoIVB gene is under dual $\sigma^{\mathrm{F}} / \sigma^{\mathrm{G}}$ control. Microbiology 142, 3453-3457.

Gomez, M. \& Cutting, S. M. (1997). Identification of a new $\sigma^{B_{-}}$ controlled gene, $c s b X$, in Bacillus subtilis. Gene (in press).

Gomez, M., Cutting, S. \& Stragier, P. (1995). Transcription of $s p o I V B$ is the only role of $\sigma^{\mathrm{G}}$ that is essential for pro- $\sigma^{\mathrm{K}}$ processing during spore formation in Bacillus subtilis. J Bacteriol 177, $4825-4827$.
Harwood, C. R. \& Cutting, S. M. (editors) (1990). Molecular Biology Methods for Bacillus. Chichester: John Wiley.

Hoch, J. A. \& Anagnostopoulos, C. (1970). Chromosomal location and properties of radiation sensitivity mutations in Bacillus subtilis. J Bacteriol 103, 295-301.

Itaya, M., Kondo, K. \& Tanaka, T. (1989). A neomycin resistance cassette selectable in a single state in the Bacillus subtilis chromosome. Nucleic Acids Res 17, 4410.

Kenney, T. J. \& Moran, C. P. (1987). Organization and regulation of an operon that encodes a sporulation-essential sigma factor in Bacillus subtilis. J Bacteriol 169, 3329-3339.

Kunkel, B., Kroos, L., Poth, H., Youngman, P. \& Losick, R. (1989). Temporal and spatial control of the mother-cell regulatory gene spoIIID of Bacillus subtilis. Genes Dev 3, 1735-1744.

Lu, S., Halberg, R. \& Kroos, L. (1990). Processing of the mother-cell $\sigma$ factor, $\sigma^{\mathrm{K}}$, may depend on events occurring in the forespore during Bacillus subtilis development. Proc Natl Acad Sci USA 87, 9722-9726.

Lu, S., Cutting, S. \& Kroos, L. (1995). Sporulation protein SpoIVFB from Bacillus subtilis enhances processing of the sigma factor precursor pro- $\sigma^{\mathbf{K}}$ in the absence of other sporulation gene products. J Bacteriol 177, 1082-1085.

Moran, C. P. (1993). RNA polymerase and transcription factors. In Bacillus subtilis and Other Gram-positive Bacteria, pp. 653-667. Edited by A. L. Sonenshein, J. A. Hoch \& R. Losick. Washington, DC: American Society for Microbiology.

Nicholson, W. L. \& Setlow, P. (1990). Sporulation, germination and outgrowth. In Molecular Biological Methods for Bacillus, pp. 391-450. Edited by C. R. Harwood \& S. M. Cutting. Chichester: John Wiley.

Oke, V. (1994). Multilevel regulation of the sporulation transcription factor $\sigma^{K}$ in Bacillus subtilis. PhD thesis, Harvard University, Cambridge, MA.

Partridge, S. R. \& Errington, J. (1993). The importance of morphological events and intercellular interactions in the regulation of prespore-specific gene expression during sporulation in Bacillus subtilis. Mol Microbiol 8, 945-955.

Perego, M. (1993). Integrational vectors for genetic manipulation in Bacillus subtilis. In Bacillus subtilis and other Gram-positive bacteria, pp. 615-624. Edited by A. L. Sonenshein, J. A. Hoch \& R. Losick. Washington, DC: American Society for Microbiology.

Popham, D. L. \& Stragier, P. (1991). Cloning, characterization and expression of the spoVB gene of Bacillus subtilis. J Bacteriol 173, 7942-7949.

Resnekov, O., Alper, S. \& Losick, R. (1996). Subcellular localization of proteins governing the proteolytic activation of a developmental transcription factor in Bacillus subtilis. Genes to Cells 1, 529-542.

Ricca, E., Cutting, S. \& Losick, R. (1992). Characterization of bof A, a gene involved in intercompartmental regulation of pro- $\sigma^{\mathbf{K}}$ processing during sporulation in Bacillus subtilis. J Bacteriol 174, 3177-3184.

Sandman, K., Kroos, L., Cutting, S., Youngman, P. \& Losick, R. (1988). Identification of the promoter for a spore coat protein gene in Bacillus subtilis and studies on the regulation of its induction at a late stage of sporulation. $J$ Mol Biol 200, 461-473.

Schaeffer, P., Millet, J. \& Aubert, J. (1965). Catabolic repression of bacterial sporulation. Proc Natl Acad Sci USA 54, 704-711.

Shazand, K., Frandsen, N. \& Stragier, P. (1995). Cell-type specificity during development in Bacillus subtilis; the molecular and morphological requirements for $\sigma \mathrm{E}$ activation. EMBO J 14, 1439-1445. 
Shinagawa, H., Makino, K., Amemura, M., Kimura, S., Iwasaki, H. \& Nakata, A. (1988). Structure and regulation of the Escherichia coli $r u v$ operon involved in DNA repair and recombination. $J$ Bacteriol 170, 4322-4329.

Stragier, P. (1992). Establishment of forespore-specific gene expression during sporulation of Bacillus subtilis. In Prokaryotic Structure and Function: a New Perspective (Society for General Microbiology Symposium 47), pp. 297-310. Edited by S. Mohan, C. Dow \& J. A. Cole. Cambridge: Cambridge University Press.

Stragier, P., Bonamy, C. \& Karmazyn-Campbelli, C. (1988). Processing of a sporulation sigma factor in Bacillus subtilis: how morphological structure could control gene expression. Cell 52, 697-704.

Sun, D. \& Setlow, P. (1993). Cloning, nucleotide sequence, and regulation of the Bacillus subtilis nadB gene and a nifS-like gene, both of which are essential for NAD biosynthesis. J Bacteriol 175 , 1423-1432.
Sun, D., Stragier, P. \& Setlow, P. (1989). Identification of a new $\sigma$ factor involved in compartmentalized gene expression during sporulation of Bacillus subtilis. Genes Dev 3, 141-149.

Trach, K. \& Hoch, J. A. (1989). The Bacillus subtilis spoOB stage 0 sporulation operon encodes an essential GTP-binding protein. $J$ Bacteriol 171, 1362-1371.

Youngman, P., Perkins, J. \& Losick, R. (1984). Construction of a cloning site near one end of $\operatorname{Tn} 917$ into which foreign DNA may be inserted without affecting transposition in Bacillus subtilis or expression of the transposon-borne erm gene. Plasmid 12, 1-9.

Zheng, L. \& Losick, R. (1990). Cascade regulation of spore coat gene expression in Bacillus subtilis. J Mol Biol 212, 645-660.

Received 10 May 1996; revised 5 August 1996; accepted 4 September 1996. 